\title{
Transferrin Receptor Protein 1
}

National Cancer Institute

\section{Source}

National Cancer Institute. Transferrin Receptor Protein 1. NCI Thesaurus. Code C38519.

Transferrin receptor protein 1 (760 aa, $\sim 85 \mathrm{kDa}$ ) is encoded by the human TFRC gene.

This protein plays a role in the transport of iron into cells. 